ON NOT BEING SOMEONE ELSE 



\title{
On Not Being Someone Else
} Tales of Our Unled Lives

ANDREW H. MILLER

\author{
II \\ III \\ Harvard University Press \\ Cambridge, Massachusetts \\ London, England \\ 2020
}


Copyright () 2020 by the President and Fellows of Harvard College

All rights reserved

Printed in the United States of America

First printing

Cover art: New York Central Park by Lincoln Seligman / Private Collection / Bridgeman Images

Cover design: Jill Breitbarth

$$
\begin{gathered}
9780674245181 \text { (EPUB) } \\
9780674245198 \text { (MOBI) } \\
9780674245204 \text { (PDF) }
\end{gathered}
$$

The Library of Congress has cataloged the printed edition as follows:

Names: Miller, Andrew H., 1964- author.

Title: On not being someone else : tales of our unled lives / Andrew H. Miller.

Description: Cambridge, Massachusetts : Harvard University Press, 2020. |

Includes bibliographical references and index.

Identifiers: LCCN 2019054803 | ISBN 9780674238084 (cloth)

Subjects: LCSH: Self in literature. | Existentialism in literature. | Identity (Psychology) in literature.

Classification: LCC PN56.S46 M55 2020 | DDC 809/.93353-dc23

LC record available at https://lccn.loc.gov/2019054803 
For Mary 
